\title{
Physiological and Molecular Characterization of Active Fungi in Pesticides Contaminated Soils for Degradation of Glyphosate
}

\section{Kelechi L. Njoku}

Environmental Biology Unit, Cell Biology and Genetics Dept., University of Lagos, Lagos

Peter O. Eludini

Environmental Biology Unit, Cell Biology and Genetics Dept., University of Lagos, Lagos

Adeola A. Adesuyi ( $\square$ biologistalex@gmail.com)

University of Lagos https://orcid.org/0000-0001-8887-7357

Emea 0. Ude

Department of Isotope Biogeochemistry, Helmholtz Centre for Environmental Research - UFZ, Leipzig, Germany

Ayodeji 0. Oyelami

Environmental and Social Studies Dept., Environmental Resources Managers Limited, Lekki, Lagos

\section{Research}

Keywords: Fungi, pesticides, glyphosate contamination, molecular characteristics, Aspergillus species, degradation, BLAST, physiological

Posted Date: June 19th, 2020

DOI: https://doi.org/10.21203/rs.3.rs-27821/v1

License: (c) (i) This work is licensed under a Creative Commons Attribution 4.0 International License. Read Full License 


\section{Abstract}

Pesticide contamination is a substantial problem in controlling agricultural pests. Understanding the physiological and molecular characteristics of naturally occurring fungi in the pesticide contaminated environment is crucial to managing glyphosate contamination. The study was aimed at isolating and characterizing soil fungi for their physiological roles towards glyphosate degradation. Pure cultures of fungi were isolated from soil contaminated with glyphosate at farms in Lagos, Nigeria. The cultures were grown on minimal salt agar media amended with glyphosate. The best isolates exhibiting good tolerance to the glyphosate were characterized using molecular techniques. The BLAST search indicated that the fungi belong to four Aspergillus species (Aspergillus flavus strain JN-YG-3-5, Aspergillus niger strain APBSDSF96, Aspergillus fumigatus strain FJAT-31052 and Aspergillus flavus strain APBSWTPF130, Trichoderma gamsii and Penicillium simplicissimum. The biodegradation study of the glyphosate by the selected fungi species showed the presence of Aminomethylphosphonic Acid (AMPA) except for Aspergillus fumigatus strain FJAT-31052. This validates AMPA as a valid pathway for degradation of glyphosate by fungi. Annotation analysis of the partial gene sequence shows that the strains possess protein coding gene clusters for glyphosate utilization and other physiological activities. A comparative genome analysis revealed that the genomes of the fungi were highly similar with genomes of environmental samples especially to Clostridium perfringens The GhostKOALA output confirmed that CYP2W1 gene (Cytochrome P450, fungi type) was present in Aspergillus fumigatus strain FJAT-31052 which was absent in genome of other fungi. The physiological and molecular characteristics of Aspergillus fumigatus strain FJAT-31052 clearly show that this isolate is a useful organism for managing contamination by glyphosate pesticide. Consequently, the isolated microorganism strains can be used in other soils as microbial inoculants for bioaugmentation combining them for their probable ability to degrade pesticides along with their biotechnological applications like enzymebased remediation.

\section{Introduction}

Glyphosate ( $\mathrm{N}$-(phosphonomethyl) glycine) pesticide is a widely used pesticides against broad spectrum of pests such as weeds, insects, fungi, nematodes and rodents in agriculture [1,2]. The intensive use of pesticides has led to an increased level and risk of contamination of the ecosystem and harmful effects on biodiversity, food security, water and other resources $[3,4,5]$. Glyphosate is a highly effective pesticide because it prevents biosynthesis of some notable proteins that are needed for plant growth and it also inhibits a specific enzyme pathway known as the shikimic acid pathway. This pathway is important for plants and some microorganisms. Studies have shown that the inhibitors of the shikimate pathway enzymes are potential herbicidal because an inhibitor of a key enzyme of plant metabolism might be herbicidal without being toxic to animals. Also, this pathway operates only in plants and microorganisms [6].

The high solubility in water and strong binding capacity to soil organic matter by glyphosate is the reason for its fast and easy distribution in ecosystems compartments [7]. The half-life of glyphosate ranges from 8.3 to 141.9 days, and it has been reported to be up to 1 year in some extreme cases [8]. The differences in rates of glyphosate degradation might be due to the changing microbial activity and extent of soilbinding. The ability of microorganisms to degrade glyphosate assumes the occurrence of enzymes cleavages by utilization of glyphosate as sources of energy. According to Sviridov et al. [9] two pathways have been proposed for glyphosate degradation, which are the AMPA pathway and the C-P lyase pathway. In the AMPA pathway, glyphosate is cleaved into aminomethylphosphonic acid (AMPA) and glyoxylate by the presence of glyphosate oxidoreductase, whereas in the C-P lyase pathway, degradation of glyphosate is catalyzed by C-P lyase with the formation of sarcosine as an intermediate product, which in the end forms formaldehyde and glycine in a reaction catalyzed by sarcosine oxidase [9].

Microorganisms known to degrade glyphosate by way of glycine comprise of Arthrobacter sp. strain GLP-1 and Pseudomonas sp. (strain PG2982) [10]. Researches have also shown that the cleavage of the C-P bond of glyphosate to produce sarcosine and finally to glycine is mediated by sarcosine oxidase-dehydrogenase $[11,12,13]$. It has also been reported that some group of bacteria, represented by a Flavobacterium sp. (Strain GDI) as well as the earlier-reported mixed bacterial cultures from soil degrade glyphosate by cleaving its carboxymethyl carbon-nitrogen bond to produce AMPA [10]. Some of the AMPA generated in this way if not further metabolized is a great concern to the environment because of their potential toxicity. This has led to mounting concern of extensive contamination of the environment resulting to likely potential risks to non-target organism due to entry into the food chain.

Despite the imminent toxicity posed by environmental threats, some organisms can still withstand glyphosate. The ability of some organisms to survive and live in a polluted environment and remediate it depends on physiological, molecular, genetic and ecological traits possessed by such organisms. Fungi are extremely important for many physiological functions in environmental assessment and protection. Their physiological and molecular determination can be useful in ecotoxicity studies and ecosystem management. Based on this we selected a farm in Nigeria where glyphosate is used as herbicides, isolated the fungi in pure culture, grow them in the medium using glyphosate as energy and study their physiological and molecular roles towards glyphosate degradation. 


\section{Materials And Methods}

\subsection{Soil samples collection}

The soil samples used for this study were obtained from two farms: Abeto Farm and Igbalu Farm in Ikorodu, Lagos, Nigeria. The selected farms have a history glyphosate organophosphorus herbicide for the last 5-6 years to control pests. Glyphosate is effectually still used to control pests at the farms. Soil samples were collected from four different points in each farm's location at 100 metres apart as described by Asef [14]. The soils were collected using a spatula at a depth of $15 \mathrm{~cm}$ and transferred to sterile containers. The soils samples were transported to the laboratory and stored at $4{ }^{\circ} \mathrm{C}$ until further analysis. Soil samples were air dried 24 hours and sieved through a $10 \mathrm{~mm}$ mesh prior to screening.

\subsection{Quantification of glyphosate content and metabolites}

Pesticides and their metabolites were analysed from the soil. The amount of glyphosate in the samples were quantified using Gas chromatography as described by Moye and Deyrup [15]. Also, aminomethylphosphonic acid (AMPA), a primary degradation product of glyphosate in the samples were assayed using the method of Ermakova et al. [16].

\subsection{Soil incubations, isolation and colony characteristics}

The isolation of glyphosate degraders from soil samples was done to screen for strains that could degrade glyphosate in liquid enrichment medium. Ten grams of soil sample was weighed on analytical balance. One gram of the sample was transferred into $90 \mathrm{ml}$ of sterile Minimum Salt Medium (MSM) broth in a $250 \mathrm{ml}$ of Erlenmeyer flask respectively and incubated at $30^{\circ} \mathrm{C}$ in a gyratory shaker for seven days. After the incubation period, $1.0 \mathrm{ml}$ of sample was withdrawn and was serially diluted using $9 \mathrm{ml}$ amount of sterile distilled water up to $10^{5}$ dilution. All the replicates of each soil type and treatment were treated separately for isolation purposes. Pesticide degraders were enriched in the dark on a shaker at $180 \mathrm{rpm}$ for seven days. The colony characteristics were examined. A second enrichment was done thereafter as described below by transferring pre-grown culture from each of the replicates to the fresh media.

\subsection{Enrichment of glyphosate degraders}

The fungi isolated from the soil samples were afterward used for the enrichment of potential glyphosate degraders. These media were further treated separately with glyphosate to enrich for glyphosate degraders. The enrichment of glyphosate degraders was carried out in liquid media by dissolving the components in $1000 \mathrm{ml}$ of distilled water and adjusting the $\mathrm{pH}$ of the basal medium to 6.0 using $1 \mathrm{M} \mathrm{NaOH} \mathrm{Solution}$. $150 \mathrm{ml}$ of the basal medium was dispensed into $250 \mathrm{ml}$ Erlenmeyer flask and the pesticide substrate was introduced into each flask at $100 \mathrm{ppm}$ after sterilization in an autoclave at $121^{\circ} \mathrm{C}$ for 15 minutes. $1.0 \mathrm{ml}$ aliquot of diluted broth culture of each isolate $\left(10^{4} \mathrm{cells} / \mathrm{ml}\right)$ were seeded into each flask and incubated in a gyratory shaker incubator at $150 \mathrm{rev} / \mathrm{min}$ at $30^{\circ} \mathrm{C}$ for a period of 32 days. The growth and enrichment ability were monitored at four-day intervals. The utilization of the pesticide fractions by the fungal isolates was evaluated by monitoring the fungal growth measured by viable count on PDA, the Optical Density (OD) at 620nm wavelength with 770 UV/Visible Light PG Spectrophotometer and changes in ionic concentration $\mathrm{pH}$ was determined with pH meter (model P2II) [17].

\subsection{Degradation of glyphosate}

The capability of the isolates to degrade glyphosate was also determined. For this purpose, the medium was supplemented with glyphosate $(100 \mathrm{ppm})$. The bacterial isolates were first grown in the medium supplemented with glyphosate to determine activity of fungi in the degradation of glyphosate.

\subsection{Biodegradation efficiency}

The percentage loss of the pesticide was calculated as:

\section{$\frac{\text { (pesticide level after contamination - pesticide level after biodegradation study) }}{\text { pesticide level after contamination }} X 100$}

While the efficiency of biodegradation was calculated using the formulae: LT - LC (Where LT is \% loss of pesticides in treatments and LC is \% loss of pesticides in control).

\subsection{Molecular characterization of isolates}

2.7.1 Colony DNA extraction and amplification by polymerase chain reaction (PCR)

Page 3/18 
Genomic DNA was extracted from the isolates using a Zymo Quick-DNA Fungal/Bacteria Micro-prep kit. After extraction, the DNA concentration and purity were checked using a ThermoScientific Nanodrop, model 2000. The extracted DNA were amplified with primers for genes used for identifying fungi. The Internal Transcribed Spacer (ITS) gene for characterization of fungi, ITS universal primer set which flanks the ITS4, 5.8S and ITS5 region was used:

- ITS4 TCCTCCGCTTATTGACATGS

- ITS5 ggaActaAAAgtcgtaAcAAgg

Polymerase chain reaction (PCR) conditions was set on an initial denaturation temperature of $94{ }^{\circ} \mathrm{C}$ for 5 minutes, followed by 35 cycles of 30 seconds denaturation at $94{ }^{\circ} \mathrm{C}, 30$ seconds annealing of primer at $55^{\circ} \mathrm{C}, 1 \frac{1}{2}$ minutes extension at $72{ }^{\circ} \mathrm{C}$ and a final extension for 7 minutes at $72{ }^{\circ} \mathrm{C}[18]$.

The amplified fragments were purified by ethanol in order to remove the PCR reagents, before they were sequenced using Applied Biosystems Genetic Analyzer 3130xl sequencer and Big Dye terminator v3.1 cycle sequencing kit. Bio-Edit and MEGA 6 were used for all genetic analysis.

The classification/identification of organisms were performed by a local nucleotide BLAST search against the non-redundant version of the NCBI ref database [19]. Phylogenetic relationship analysis was performed on the sequences of isolated microorganisms using Molecular Evolutionary Genetics Analysis version 6 [19]. The sequences were prepared using FASTA format and aligned using ClustaW option of the program [19]. The phylogenetic dendrogram was constructed using the maximum likelihood with 1000 bootstrap.

\subsubsection{Genome sequence annotation}

The annotation of protein-coding genes was provided by FGENESB; further gene prediction and functional annotation were performed by GhostKOALA. The pathways of selective compounds were interpreted using KEGG pathway chart.

\subsection{Statistical analysis}

All data set were analyzed using GraphPad prism 7.0. Significant means were separated using multiple comparison of two-way analysis of variance. Correlation analysis was done to compare the relationship between pesticide degradation, colony count, optical density and $\mathrm{pH}$. Data obtained from the enzyme studies were subjected to Dunnett's test and Tukey's multiple T-test and two-way analysis of variance (ANOVA) where it was applicable.

\section{Results}

\subsection{Characterization of the soil from the locations}

In this study, the soils were initially characterized to have a baseline concentration of glyphosate in relation to fungal distribution. All the locations had evidence of glyphosate contamination though the contamination levels varied depending on location (Fig. 1) and they were significant $(p<0.05)$. Location 1 had the highest contamination comprising $319.1 \mathrm{mg} / \mathrm{kg}$ glyphosate and $194.2 \mathrm{mg} / \mathrm{kg}$ AMPA. Location 3 showed increased glyphosate level without transformation product (AMPA). Among the locations, the lower level of glyphosate was observed more rapid in location 4 with only traces of glyphosate present $(6.98 \mathrm{mg} / \mathrm{kg})$.

Correspondingly, the fungal density varied within the location (Fig. 2). There was high enumeration of fungal count in locations where AMPA concentration was high and with significant concentrations of glyphosate. However, other locations where AMPA concentration was low or absent had low fungal count. This implies active metabolic state of the fungi. As a result, this study evaluates the relationship between the fungal density, glyphosate and AMPA. The Pearson correlation shows that fungal load is significantly related to AMPA ( $r=0.94965 ; p \leq 0.05)$ in comparison to glyphosate.

\subsection{Selection and isolation of glyphosate degraders}

A total of 14 isolates were obtained from the farms (Table 1). The fungal inoculum from soils enrichment were plated on MSM agar plates to check for their ability to grow in presence of glyphosate on solid media. It was observed that S1b, S1c, S2.3, S3.2, S3.3, S4.1 and S4.4 isolates did not grow from any of the enriched soils on MSM agar when glyphosate was added externally, during the set incubation time. They displayed poor (+) clear zone, therefore, no further analysis was conducted on them. The isolates that showed good (++) clear zone (S1a, S1d, S2.1, S3.1, S4.1 and S4.3) were further analyzed for their ability to degrade glyphosate (Table 2). A total of six (6) potential degraders were obtained after successive sub-culturing from the soils. 
Six fungal isolates were stimulated to grow in the presence of glyphosate. The glyphosate mixed with MSM showed enhanced growth of some fungal isolates as shown by their optical density which ranged from $93.47 \%$ in P. simplicissimum SNB-VECD $11 \mathrm{G}$ to $96.64 \%$ in $T$. gamsii P2-18 (Table 3). Furthermore, the growth of fungal isolates, A. fumigatus FJAT-31052 and A. flavus EFB01 were promoted and they tolerated the glyphosate as they continued growing till the Day 32 where the experiment ended. Whereas, growth promotion of other fungal isolates was inhibited after the Day 28. More so, the fungal growth in the presence of glyphosate caused a decrease in the $\mathrm{pH}$ of the environment from 6.0 to 4.7 in all the isolates (Table 4).

The changes were all significant $(P<0.05)$ with increasing incubation times but were not significant $(P>0.05)$ within the isolates. The change in $\mathrm{pH}$ was more obvious in A. flavus EFB01 (22.06\%) and lowest in A. flavus JN-YG-3-5 (19.21\%). Therefore, the fungal growth was inversely proportional with the $\mathrm{pH}$.

The analysis of viable fungal count in all the samples at different days varied (Figure 3). Three major phases of growth were identified in all the isolates. These includes lag phase, exponential phase and death phase. These phases were similar in all the fungi. The lag phase lasted for 8 days (day 0 to day 8), thereafter a slight but non increase in growth from day 8 to day 16 . The exponential phase started from day 16 to day 24 and death phase started after day 24 . The peak of the growth was on the $24^{\text {th }}$ day. On this day, the maximum fungal count was 1.09+E06 CFU by A. fumigatus FJAT-31052 and the lowest was 6.20+E05 CFU by T. gamsii P2-18. All other isolates growths were significant.

\subsection{Degradation of glyphosate}

The potential ability of the six fungal strains for glyphosate biodegradation were observed for 32 days (Fig. 4). The strain T. gamsii P2-18 sp. degraded $91.45 \%$ of glyphosate leaving $930.81 \mathrm{mg} / \mathrm{kg}$ of AMPA. In addition, it was observed that there was $92.07 \%$ glyphosate degradation when inoculated with A. niger APBSDSF96 leaving 113.53 mg/kg AMPA (Fig. 5). Interestingly, A. flavus JN-YG-3-5 utilized 92.86\% without accumulation of AMPA; this had the highest extent of degradation.

Overall, an analysis of the degradation efficiency of the fungi strains in glyphosate degradation showed that the isolates were efficient degraders with percentage degradation above $90 \%$ (Fig. 6). However, A. flavus EFB01 had the poorest percentage degradation (27.17\%) indicating poor metabolism of glyphosate. The degradation efficiency of A. flavus JN-YG-3-5 was the most efficient fungi (85.6\%) (Fig. 6).

\subsection{Molecular characteristics}

The molecular characteristics of these promising isolates are shown in Table 5. BLAST analysis (ITS gene sequence) carried out through NCBI GenBank showed that the first two bacterial sequences were identified as strains of $T$. gamsii P2-18 (94.57\% similarity) and A. flavus JN-YG-35 (99.28\% similarity), respectively. Other isolates were identified as Aspergillus niger APBSDSF96 (95.22\%) similarity, A. fumigatus FJAT-31052 (99.30\%) similarity, A. flavus EFB01 (99.29\%) similarity and P. simplicissimum SNB-VECD11G (89.91) similarity. The isolates had high level of GC contents ranging from 53.54\% in P. simplicissimum SNB-VECD11G to 58.66\% in Aspergillus flavus JN-YG-3-5 suggesting their potential for environmental management.

The ITS gene sequence showed that all the six isolates clustered into three group (Penicillum sp., Trichoderma sp. and Aspergillus sp.) (Fig. 7) for phylogeny analyses of the isolates. Aspergillus flavus JN-YG-3-5 clustered with genus Aspergillus flavus EFB01 showing similarity, they distantly clustered with Aspergillus niger APBSDSF96 and Aspergillus fumigatus FJAT-31052. However, Trichoderma gamsii P2-18 and Penicillium simplicissimum SNB-VECD11G out clustered.

\subsection{Bacteria genome annotation}

Automated annotation identified several genes using a statistical significance threshold (Table 6). The genome sequences of the fungi were compared to those of several organisms (Archae generic, C. pefringes, B. subtilis and $P$. putida) known to function in metabolic processes. Validation of the sequence annotation using the FGENESB database yielded the following result: Rhizobium huautlense comprises 5 potential protein coding genes, 1 operon and 4 transcription units. Pseudomonas aeruginosa strain MZ4A contains 11 protein genes, 1 operon and 7 transcriptional units. Pseudomonas aeruginosa strain $22 A B U H 7$ had 5 protein genes, 1 operon and 3 transcriptional units. Bacillus subtilis strain VBN01 had 8 protein genes, 1 operon and 5 transcriptional units. Pseudomonas aeruginosa strain HS-38 sequence was made up of 6 potential protein coding genes, 1 operon and 5 transcriptional units. Pseudomonas aeruginosa strain MZ4A and Pseudomonas aeruginosa strain HS-38 had potential protein coding genes similar to Pseudomonas putida while others did not. A search of the identified proteins for specific functions revealed that the genes are distributed in different functional categories majorly protein metabolism and respiration (Table 7). Numerous genes associated with pesticide degradation were identified.

\section{Discussion}

Our findings showed that the topsoil from the farms in various locations contain residues of herbicide chemical glyphosate and its metabolite, AMPA. This can be attributed to the over-reliance of this chemical in agricultural practices. However, the concentration of this glyphosate in the field was found to be relatively higher than published work on Environmental Health Criteria 159 under the sponsorship of United Nations 
Environment Programme, the International Labour Organisation, and the World Health Organization [7]. Therefore, this calls for serious remedial action to be taken as the accumulation of glyphosate is likely to pose serious danger to ecological receptors.

Notwithstanding the diversity of organisms present in the contaminated site, our interest was majorly on fungi as little is known on their role for biodegradation of glyphosate. There was high enumeration of fungal count in location where AMPA level was remarkably high as well as relatively high level of glyphosate compared to lower levels. This was also supported by the pearson correlation which shows high correlation with AMPA. A range of bacterial strains have been implicated to be abundant in glyphosate contaminated environment either because of their capability of using the compound as sole source of phosphorus, carbon or nitrogen [20]. As such they play a role in degradation. Therefore, investigation of the role of diversities of fungi in the degradation of glyphosate can be remarkably interesting.

In order to isolate potential fungi to degrade glyphosate we observed the enhanced growth of these microbes from the four soil locations. Only six isolates from all the location demonstrated enhanced growth in the presence of glyphosate. This shows their ability to use glyphosate as an energy source. However, the inability of the other isolates to survive could be the toxic effect of glyphosate on the organisms. Eman et al. [21] noted that application of pesticides has the possibility to exert some effects on non-target organisms, plus the soil microorganisms. Presence of pesticides makes some microorganisms to lyse while other microorganisms may be resistant and tolerant to a pollutant, hence, increase in their numbers and biomass due to decreased competition [21].

In studying the effect of glyphosate on the activities of the fungi in the enriched medium supplemented with glyphosate, the pure isolates induced changes in the medium such as changes in $\mathrm{pH}$, optical density, and fungal counts. The decrease in the $\mathrm{pH}$ levels of the culture medium may be as a result of microbial metabolism and production of secondary metabolites. Analysis of supernatants by Montserrat et al. [22] also demonstrated a decrease in $\mathrm{pH}$ resulting from rapid production of lactic, acetic, pyruvic and citric acids. The implication is that such changes in $\mathrm{pH}$ can influence bacteria growth. For instance, Yang et al. [23] found out that pH level of culture medium was one of the key factors influencing the growth of four bacteriocinogenic strains. Furthermore, LeBlanc et al. [24] stated that the growth of Lactobacillus fermentum CRL 722 was noticeably slower at $\mathrm{pH} 4.5\left(\mu_{\max }=0.78 \mathrm{~h}^{-1}\right)$ than at other $\mathrm{pH}$ values including $\mathrm{pH} 5.0,5.5$, and $6.0\left(\mu_{\mathrm{max}}=1.15-\right.$ $\left.1.25 \mathrm{~h}^{-1}\right)$. This is in agreement with results obtained in this study which shows that optimum growth of fungi under glyphosate was obtained at approximately 5.0. This might also influence bioremediation activity. Therefore, changes in metabolic state of the fungal can be the driving force of the $\mathrm{pH}$ suggesting active state of the fungal cells. Longer lag phase (16 days after inoculation) could suggest that fungal enrichment in glyphosate treated medium may be slower than bacteria. However, efficiency in transformation of glyphosate need to be evaluated. The short exponential phase could suggest active state of the fungi towards glyphosate remediation. Stratton and Stewart [25] observed a small rise in microbial biomass but no negative or positive effects in respect to the number of microorganisms. In addition, Haney et al. [26] and Busse et al. [27] assessed the effect of glyphosate on soil's microbial community and their findings concluded that microbial activity was stimulated even in the presence of this herbicide. Therefore, it is prospective that the glyphosate provided nutrients for fungal growth, as shown by the significant growth and increase in microbial population.

Glyphosate is a nonselective, broad-spectrum, post-emergence herbicide that is widely used in agriculture; hence, degradation of the compound will be a positive obligation in agricultural practices. It was evident that the isolates of fungal strains degraded glyphosate. The growth ability of the fungal strains could ascertain a significant assimilation of glyphosate. One reason could be that the fungal strains exhibited optimal growth rates, in order to potentially adapt to the glyphosate concentration and to assimilate it. Also, it is possible that they possess enzymes capable of cleaving the $\mathrm{C}-\mathrm{P}$ bond. It is remarkable to mention that this assimilation took place without enhancement by sucrose, nitrogen (N), and phosphorus source. For example, Eman et al. [21] reported that a concentration of 1\% sucrose was important for the initial stimulation of fungal strains in glyphosate degradation. Studies reported that the development of enhanced degradation of xenobiotics or pollutants depends on multiple factors such as nutrient composition, chemical structure, soil properties including the presence of degrading microbes with appropriate metabolic functions $[28,29]$. Our aim was to isolate the key player of glyphosate degrading fungi from soils which demonstrated rapid degradation capability. The intensity of glyphosate biodegradation with the indigenous microbial pure strain was highest in A. flavus JN-YG-3-5 which utilized 92.86\% without accumulation of AMPA. Thus, this makes it so interesting for environmental application. Other strains had high capability but produced AMPA which might be detrimental to the environment.

Aspergillus $s p$ have received tremendous interest for their suitability in bioremediation [30]. This could be the reason scientists and environmentalist are interested to develop various strategies for the use of Aspergillus sp. in bioremediation. This species will be useful in pesticide contaminated soil. Different species of fungi were identified using BLAST analysis. The high abundance of Aspergillus species in the samples may be due to their ability to tolerate and degrade pesticides. Similar studies have been conducted by Asef, [14] and have revealed the isolation, molecular characterization and pesticide degradation by Aspergillus species. Thus the reason Aspergillus sp have received tremendous interest for suitability to remediate wide range of xenobiotic compounds. The identified fungal strains observed in this study have high GC contents. This is likely to have made them tolerant to pesticide. One imperative property of the GC base pair is its higher thermal stability than the AT base pair. An increase in GC content correlates with a broader tolerance range of species [31]. 
The range of GC contents in the fungi suggests characteristics of microbe from soil. Aspergillus flavus JN-YG-3-5 can be a particularly important tools for use in biotechnology because it yielded high pure DNA quantity and has a GC content similar to well-known GC in soil for active physiological functions. The works of Smarda et al [31] and Njoku et al. [18] reported that GC-rich genes facilitate the response to environmental stress. In addition, it can also facilitate complex gene regulation. Thus, improved responses to environmental conditions might be enabled by GC-rich genes. The fungi having higher GC contents were better in glyphosate degradation thus giving a beneficial advantage to be utilized in a wide range of environmental applications. This could have also been an added advantage to Aspergillus flavus JN-YG-3-5 for complete mineralization of glyphosate pesticide.

Phylogenetic analysis explicitly showed that the polluted soil sheltered diverse fungi population belonging to three clusters of orthologous groups with Aspergillus flavus JN-YG-3-5 clustering together suggesting their similar ancestry. It can also be due to combination of selective factors, proximity and functional capacity [32]. The different groups that they belong to does not necessarily mean that they degraded the contaminant through different processes. It has been hypothesized that phylogenetically distant lineages might share mutual functions and functional features. The work agreed with the work of Ning and Beiko [32] who reported that functional similarities exist between operational taxonomic units (OTUs) that belong to different high-level taxonomic groups for fungi.

Automated annotation identified several proteins within the genome of fungal strains to include ABC transporters, these are members of a protein superfamily known to be involved in the efflux of drugs from the cells of target organisms. Also, the Zinc finger protein gene and zinc finger chimera 1, were discovered along with many oxidoreductase genes. A search of the identified proteins for specific functions revealed that the genes are distributed in different functional categories majorly protein metabolism and respiration. Numerous genes associated with pesticide degradation were identified.

Interestingly, The GhostKOALA output identified CYP2W1 gene (Cytochrome P450, fungi type) present in Aspergillus fumigatus strain FJAT31052 which was absent in genome of other fungi. The cytochrome P450 enzymes are monooxygenases which catalyze many active reactions involved in the metabolism of wide variety of xenobiotics [33]. Previous studies have reported the activities of human CYPs involved in the metabolism of pesticides [34, 35]. CYP-pesticides interactions are by either the induction or inhibition of the metabolizing enzymes. In a study by Khaled et al. [33] HepaRG cells express a large panel of liver-specific genes including several CYP enzymes, which contrasts with HepG2 cell lines. Both immunoblotting and reverse transcription polymerase chain reaction (RT-PCR) techniques have been used to examine the pesticide-CYP induction [33, 36, 37].

Although fungi have received tremendous interest for their suitability in detoxifying a variety of contaminants, its ability to degrade glyphosate is a new area of research interest. Two different routes have been proposed to be utilize by soil microorganisms to metabolize glyphosate: The C-P lyase and AMPA pathways [9]. To demonstrate the valid pathway, identification of AMPA even to a significant amount shows that AMPA pathway is valid. This mechanism involves the oxidative cleavage of the $\mathrm{C}-\mathrm{N}$ bond on the carboxyl side catalyzed by glyphosate oxidoreductase (GOX) which results in the formation of aminomethylphosphonic acid (AMPA) and glyoxylate. The mechanism for detoxification of glyphosate was suggested by activities of certain enzymes that catalyzes the reaction such as: oxidoreductases that cleave $\mathrm{C}-\mathrm{N}$ with stoichiometric formation of glyoxylate and aminomethylphosphonic acid (AMP) [6]. Aminotransferase which catalyses the conversion of AMP to phosphonoformaldehyde. Phosphonatase which catalyze the cleavage of phosphonoacetaldehyde $\mathrm{C}-\mathrm{P}$ bond to form acetalde-hyde. It was evident and validated from the annotated gene results that dehydrogenase/oxidoreductase related pathway is valid by the presence of dehydrogenase related protein (alcohol dehydrogenase) discovered in their genome.

\section{Conclusion}

In this study, novel glyphosate-degrading fungi strains were isolated from farm soils in Nigeria. All strains used for enhanced biodegradation grew in the presence of glyphosate and were able to degrade glyphosate. This is the first report to show fungal degradation of glyphosate from Nigerian soil. The use of these indigenous fungal strains promises to be effective in practical application of bioremediation of glyphosate since the microbes have already adapted to the localized habitat conditions. The essence of this is that isolated strains can also be added to other soils as microbial inoculants for their potential to degrade pesticides by improving soil quality for sustainable agriculture and environment. This study has provided strains with biodegrading genes, enzymes and pathways to be harnessed for a range of biotechnological and bioremediative applications. It provides novel insights into specialised organisms for active bioremediation. The physiological and molecular characteristics shows that Aspergillus species are useful organism for managing contamination by glyphosate pesticide.

\section{Declarations}

\section{Availability of data and materials}


All generated or analysed data during this study are included in this published article and are also available from the corresponding author upon request.

\section{Competing Interest}

The authors declare that they have no competing interests.

\section{Funding}

Not applicable.

\section{Authors' Contribution}

KLN, EOP and AAA carried out the design and development of the research idea. EOP and EOU carried out the biological and technical experiments. AOO, AAA and KLN carried out formal analyses and review. All the authors read, agreed and approved the final manuscript made by $A A A$.

\section{Acknowledgements}

The authors are grateful to Laboratory/Technical staff of Department of Microbiology and Cell Biology and Genetics Department University of Lagos for their support and resources in carrying out this research work.

\section{Corresponding Author}

Correspondence to Adeola A. Adesuyi (Ph.D.)

\section{References}

1. Azmi, A, Naqvi H. Pesticide Pollution, Resistance and Health Hazards. Pesticides- The Impacts of Pesticides Exposure. Accessed 10th September, 2018. <http://cdn.intechopen.com/pdfs/13220/InTechPesticide_pollution_resistance_and_health_hazards.pdf>. 2011.

2. Usman S. Soil Challenges by Pesticide: An Illustrated Concept for Environmental Awareness. Journal of Ecology and Toxicology 2018; 2(1):109-113. https://www.omicsonline.org/open-access/soil-challenges-by-pesticide-an-illustrated-concept-for-environmentalawareness-97814.html.

3. Queyrel W, Habets F, Blanchoud H, Ripoche D, Launay M. Pesticide fate modeling in soils with the crop model STICS: Feasibility for assessment of agricultural practices. Science of the Total Environment 2016; 542: 787-802.

4. Njoku KL, Ulu Z, Adesuyi AA, Jolaoso AO, Akinola MO. Mycoremediation of Dichlorvos Pesticide Contaminated Soil by Pleurotus pulmonarius (Fries) Quelet. J Poll. 2018; 4(4):605-615. https://jpoll.ut.ac.ir/article_67647.html.

5. Adesuyi, A.A., Njoku, K.L. Akinola, M.O., and Nnodu, V.C. (2018). Pesticides related knowledge, attitude and safety practices among smallscale vegetable farmers in lagoon wetlands, Lagos, Nigeria. JAIED. 112(1):81-99. http://www.jaeid.it/index.php/JAEID/article/view/697.

6. Hove-Jensen B, David LZ, Bjarne J. Utilization of Glyphosate as Phosphate Source: Biochemistry and Genetics of Bacterial CarbonPhosphorus Lyase. Journal of American Society for Microbiology, 2014;78:176-197.

7. International Programme on Chemical Safety (IPCS). The Environmental Health Criteria 159: Glyphosate. ISBN 924157159 4. VAMMALA: pp134; 1994.

8. Oppenhuizen ME. The terrestrial field dissipation of glyphosate: final report. Unpublished report MSL-12651. Monsanto Company, St. Louis, MO. As cited in Giesy et al, 2000; 1993.

9. Sviridov AV, Shushkova TV, Zelenkova NF, Vinokurova NG, Morgunov IG. Distribution of glyphosate and methylphosphonate catabolism systems in soil bacteria Ochrobactrum anthropic and Achromobacter sp. Applied Microbiology and Biotechnology, 2011;93: 787-796.

10. Jacob GS, Barbow JR, Hallas LE, Kimack NM, Kishore GM. Metabolism of glyphosate in Pseudomonas sp. strain LBr. Applied Environmental Microbiology, 1988; 54:2953-2958.

11. Kishore GM, Jacob GS. Degradation of glyphosate by Pseudomonas sp. PG2982 via a sarcosine intermediate. Journal of Biology and Chemistry, 1987; 262:12164-12168.

12. Pipke R, Amrhein N, Jacob GS, Schaefer J, Kishore, GM. Metabolism of glyphosate in an Arthrobacter sp.GLP-1. European Journal Biochemistry, 1987;165:267-273.

13. Shinabarger DL, Braymer HD. Glyphosate catabolism by Pseudomonas sp. strain PG2982. Journal of Bacteriology, 1986;168:702-707. 
14. Asef IM. Isolation of pesticide degrading microorganisms from soil. Advances in Bioresearch, 2014;5(4):164-168. https://www.researchgate.net/publication/280839311_Isolation_of_Pesticide_Degrading_Microorganisms_from_soil.

15. Moye A, Deyrup L. A Single-Step derivatization method for the gas chromatographic analysis of the herbicide glyphosate and its metabolite. Journal of Agricultural Food Chemistry, 1984;32:192-195.

16. Ermakova IT, Shushkova TV, Leontievsky AA. Microbial degradation of organophosphonates by soil bacteria. Microbiology, 2008;77:615620.

17. Nwaogu A, Onyeze C, Nwabueze N. Degradation of diesel oil in polluted soil using Bacillus subtilis. African Journal of Biotechnology, 2008;7:1939-1943.

18. Njoku KL, Asunmor MO, Ude EO, Adesuyi AA, Oyelami AO. The Molecular Study of Microbial and Functional Diversity of Resistant Microbes in Heavy Metal Contaminated Soil. Environmental Technology and Innovation, 2020;17:100606.

19. Tamura K, Stecher G, Peterson D, Filipski A, Kumar S. MEGA6: Molecular evolutionary genetics analysis version 6.0. Molecular Biology and Evolution, 2013;30(12):2725-2729.

20. Hove-Jensen B, David LZ, Bjarne J. Utilization of Glyphosate as Phosphate Source: Biochemistry and Genetics of Bacterial CarbonPhosphorus Lyase. Journal of American Society for Microbiology, 2014;78:176-197.

21. Eman A, Sadik, M.W., Abdel-Megeed A, Suliman AA, Sholkamy EN. Biodegradation of Glyphosate by fungal strains isolated from herbicides polluted-soils in Riyadh area. Current Microbiology and Applied Science, 2013;2(8):359-381.

22. Montserrat S, Núria R, José L. Rapid extracellular acidification induced by glucose metabolism in non-proliferating cells of Serratia marcescens. International Journal of Microbiology, 2000;3:39-43.

23. Yang E, Fan L, Yan J, Yueming C, Doucette F, Bradley W. Influence of culture media, pH and temperature on growth and bacteriocin production of bacteriocinogenic lactic acid bacteria. AMB Express. 2018; 8:10-14.

24. LeBlanc G, Garro S, Savoy de Giori G. Effect of pH on Lactobacillus fermentum growth, raffinose removal, a-galactosidase activity and fermentation products. Applied Microbiology and Biotechnology, 2004;65:119-123.

25. Stratton GW, Stewart KE. Glyphosate effects on microbial biomass in a coniferous forest soil. Environmental Toxicology and Water Quality, 1992;17(3):223-236.

26. Haney RL, Senseman SA, Hons EM, Zuberer DA. Effect of glyphosate on soil microbial activity and biomass. Weed Science, 2000;48:8993.

27. Busse MD, Ratcliff AW, Shestak CJ. Glyphosate toxicity and the effects of long-term vegetation control on soil microbial communities. Soil Biol. Biochem. 2001;33(12-13): 1777-1789. https://www.fs.fed.us/psw/publications/busse/2001_sdarticle.pdf.

28. Rayu S, Nielsen UN, Nazaries L, Singh BK. Isolation and Molecular Characterization of Novel Chlorpyrifos and 3,5,6-trichloro-2-pyridinoldegrading Bacteria from Sugarcane Farm Soils. Frontiers in Microbiology, 2017;8:518.

29. Kumar D, Pannu R. Perspectives of lindane ( $\gamma$-hexachlorocyclohexane) biodegradation from the environment: a review. Bioresour. Bioprocess. 2018;5:29. https://doi.org/10.1186/s40643-018-0213-9

30. Mukherjee A. Role of Aspergillus in bioremediation process, p 209-214. In Gupta V (ed), New and future developments in microbial biotechnology and bioengineering. Elsevier, Amsterdam, The Netherlands, 2016.

31. Smarda P, Petr B, Lucie H, Ilia JL, Ladislav M, Ettore P, Lubomír T, Vít G, Olga R. Ecological and evolutionary significance of genomic GC content diversity in monocots. Proc Natl Acad Sci U S A. 2014;111(39):E4096-102.

32. Ning J, Beiko RG. Phylogenetic approaches to microbial community classification. Microbiome. 2015;3:47.

33. Khaled A, Miia T, Arja R, Jukka H, Olavi P. Metabolism of Pesticides by Human Cytochrome P450 Enzymes In Vitro - A Survey. Insecticides - Advances in Integrated Pest Management, 2012:167-194. ISBN: 978-953-307-780-2.

34. Hodgson E. In vitro human phase I metabolism of xenobiotics I: Pesticides and related compounds used in agriculture and public health. Journal of Biochemistry and Molecular Toxicology, 2003;17(4):201-206.

35. Hodgson E. Pesticide Biotransformation and Disposition. Academic Press, 1 Jan 2012. 234 pp.

36. Wyde ME, Bartolucci E, Ueda A, Zhang H, Yan B, Negishi M, You L. The Environmental Pollutant 1,1-Dichloro-2,2-bis(pchlorophenyl)ethylene Induces Rat Hepatic Cytochrome P450 2B and 3A Expression through the Constitutive Androstane Receptor and Pregnane X Receptor. Mol Pharmacol, 2003;64(2):474-481.

37. Lemaire G, de Sousa G, Rahmani R. A PXR reporter gene assay in a stable cell culture system: CYP3A4 and CYP2B6 induction by pesticides. Biochemistry and Pharmacology, 2004;681(2):2347-2358.

https://www.sciencedirect.com/science/article/abs/pii/S0006295204005593?via\%3Dihub

\section{Tables}

Page 9/18 
Table 1

Summary of the fungal culture characteristics

\begin{tabular}{|c|c|c|c|c|c|}
\hline \multirow[t]{2}{*}{ Isolate code } & \multirow[t]{2}{*}{ Colour/pigment } & \multirow[t]{2}{*}{ Growth of Isolate on AGAR + Herbicide } & \multicolumn{3}{|c|}{ Substrate specificity (Optical Density at $620 \mathrm{~nm}$ ) } \\
\hline & & & Day 0 & Day 4 & Day 7 \\
\hline S1a & Greenish Yellow & ++ & 0.056 & 0.261 & 0.569 \\
\hline $\mathrm{S} 1 \mathrm{~b}$ & White & + & 0.034 & 0.133 & 0.166 \\
\hline S1c & Green & + & 0.042 & 0.158 & 0.386 \\
\hline S1d & Black & ++ & 0.063 & 0.246 & 0.399 \\
\hline S2.1 & Yellow & ++ & 0.052 & 0.258 & 0.421 \\
\hline S2.2 & Brown & ++ & 0.076 & 0.274 & 0.481 \\
\hline S2.3 & Green & + & 0.039 & 0.144 & 0.383 \\
\hline S3.1 & Green & ++ & 0.048 & 0.261 & 0.493 \\
\hline S3.2 & Green & + & 0.035 & 0.147 & 0.171 \\
\hline S3.3 & White & + & 0.041 & 0.166 & 0.352 \\
\hline S4.1 & Green & ++ & 0.059 & 0.241 & 0.581 \\
\hline S4.2 & Grayish Green & + & 0.033 & 0.193 & 0.236 \\
\hline S4.3 & White & ++ & 0.038 & 0.186 & 0.311 \\
\hline S4.4 & Brown & + & 0.061 & 0.263 & 0.461 \\
\hline
\end{tabular}

Key: + poor clear zone, ++ good clear zone; S1 - Soil 1; Sla, S1b and Slc (1st, 2nd and 3rd isolates from soil 1); S2 - Soil 2; S2.1, S2.2 and S2.3 (1st, 2nd and 3rd isolates from soil 2); S3 - Soil 3; S3.1, S3.2 and S3.3 (1st, 2nd and 3rd isolates from soil 3); S4 - Soil 4; S4.1, S4.2, S4.3 and S4.4 (1st, 2nd, 3rd and 4th isolates from soil 4).

Table 2

The selected isolates, locations and identities.

\begin{tabular}{|lllll|}
\hline Selected isolate & Source & Organisms Name & Identity (\%) & E-Value \\
\hline S1a & Location 1 & Trichoderma gamsii P2-18 & 94.57 & 0.0 \\
\hline S1d & Location 1 & Aspergillus flavus JN-YG-3-5 & 99.28 & 0.0 \\
\hline S2.1 & Location 2 & Aspergillus niger APBSDSF96 & 95.22 & 0.0 \\
\hline S3.1 & Location 3 & Aspergillus fumigatus FJAT-31052 & 99.30 & 0.0 \\
\hline S4.1 & Location 4 & Aspergillus flavus EFB01 & 99.29 & ISE \\
\hline S4.3 & Location 4 & Penicillium simplicissimum SNB-VECD11G & 89.91 & $2 \mathrm{2}-147$ \\
\hline
\end{tabular}


Table 3

Effect of microbial growth on optical densities

\begin{tabular}{|c|c|c|c|c|c|c|c|c|c|c|}
\hline \multirow[t]{2}{*}{ Sample Code } & \multirow{2}{*}{$\begin{array}{l}\text { Day } \\
0\end{array}$} & Day & Day & Day & Day & Day & Day & Day & Day & \multirow[t]{2}{*}{ \%Change } \\
\hline & & 4 & 8 & 12 & 16 & 20 & 24 & 28 & 32 & \\
\hline T. gamsii P2-18 & 0.03 & $0.194^{\star \star}$ & $0.461^{\star \star \star \star}$ & $0.521^{\star \star \star \star}$ & $0.611^{\star \star \star \star}$ & $0.784^{\star \star \star \star}$ & $0.843^{\star \star \star \star}$ & $0.936^{\star \star \star \star}$ & $0.894^{\star \star \star \star}$ & 96.64 \\
\hline A. flavus JN-YG-3-5 & 0.04 & $0.19^{\star *}$ & $0.341^{\star \star \star \star}$ & $0.491^{\star \star \star \star}$ & $0.601^{\star \star \star \star}$ & $0.668^{\star \star \star \star}$ & $0.752^{\star \star \star \star}$ & $0.804^{\star \star \star \star}$ & $0.788^{\star \star \star \star}$ & 94.92 \\
\hline A. niger APBSDSF96 & 0.03 & $0.286^{\star *}$ & $0.39^{\star \star \star \star}$ & $0.486^{\star \star \star \star}$ & $0.592^{\star \star \star \star}$ & $0.693^{\star \star \star \star}$ & $0.804^{\star \star \star \star}$ & $0.911^{\star \star \star \star}$ & $0.883^{\star \star \star \star}$ & 96.60 \\
\hline $\begin{array}{l}\text { A.fumigatusFJAT- } \\
31052\end{array}$ & 0.04 & $0.298^{\star \star}$ & $0.48^{\star \star \star \star}$ & $0.567^{\star \star \star \star}$ & $0.563^{\star \star \star \star}$ & $0.799^{\star \star \star \star}$ & $0.876^{\star \star \star \star}$ & $0.962^{\star \star \star \star}$ & $0.998^{\star \star \star \star}$ & 95.99 \\
\hline A. flavus EFB01 & 0.05 & $0.24^{\star \star \star}$ & $0.369^{\star \star \star \star}$ & $0.434^{\star \star \star \star}$ & $0.563^{\star \star \star \star}$ & $0.616^{\star \star \star \star}$ & $0.698^{\star \star \star \star}$ & $0.786^{\star \star \star \star}$ & $0.793^{\star \star \star \star}$ & 93.69 \\
\hline $\begin{array}{l}\text { P. simplicissimum } \\
\text { SNB-VECD } 11 \mathrm{G}\end{array}$ & 0.05 & $0.323^{\star \star}$ & $0.399^{\star \star \star \star}$ & $0.486^{* \star \star *}$ & $0.573^{\star \star \star \star}$ & $0.646^{* \star \star *}$ & $0.766^{\star \star \star \star}$ & $0.809^{\star \star \star \star}$ & $0.766^{\star \star \star \star}$ & 93.47 \\
\hline
\end{tabular}

Table 4

Summary of $\mathrm{pH}$ changes with respect to days

\begin{tabular}{|c|c|c|c|c|c|c|c|c|c|}
\hline Sample code & Day 0 & Day 4 & Day 8 & Day 12 & Day 20 & Day 24 & Day 28 & Day 32 & $\begin{array}{l}\% \text { change } \\
\text { in } \mathrm{pH}\end{array}$ \\
\hline T. gamsii P2-18 & 6.06 & 6.00 & $5.00^{\star \star \star \star}$ & 5.76 & $5.30^{\star *}$ & $5.00^{\star \star \star \star}$ & $4.86^{\star \star \star \star}$ & $4.75^{\star \star \star \star}$ & 21.62 \\
\hline A. flavus JN-YG-3-5 & 6.04 & 5.96 & 5.80 & 5.66 & 5.44 & $5.24^{\star \star}$ & $5.06^{* \star *}$ & $4.88^{\star \star \star \star}$ & 19.21 \\
\hline A. niger APBSDSF96 & 6.06 & 5.99 & 5.84 & 5.74 & $5.33^{* *}$ & $5.16^{\star \star \star}$ & $4.92^{\star \star \star \star}$ & $4.79^{\star \star \star \star}$ & 20.96 \\
\hline A.fumigatusFJAT-31052 & 6.05 & 6.01 & 5.81 & 5.63 & $5.22^{\star \star}$ & $5.03^{\star \star \star \star}$ & $4.89^{\star \star \star \star}$ & $4.73^{\star \star \star \star}$ & 21.82 \\
\hline A. flavus EFB01 & 6.03 & 5.96 & 5.82 & 5.50 & $5.10^{\star \star \star}$ & $4.96^{\star \star \star \star}$ & $4.83^{\star \star \star \star}$ & $4.70^{\star \star \star \star}$ & 22.06 \\
\hline P. simplicissimum SNB-VECD11G & 6.04 & 5.95 & 5.78 & 5.46 & $5.18^{\star \star \star \star}$ & $5.00^{\star \star \star \star}$ & $4.90^{\star \star \star \star}$ & $4.82^{\star \star \star \star}$ & 20.20 \\
\hline
\end{tabular}

Table 5

Molecular characteristics of the isolates

\begin{tabular}{|l|l|l|l|l|}
\hline Organisms Name & Identity (\%) & E-Value Sequence length (Bp) & \% Guanine-Cytosine \\
\hline Trichoderma gamsii P2-18 & 94.57 & 0.0 & 589 & 56.71 \\
\hline Aspergillus flavus JN-YG-3-5 & 99.28 & 0.0 & 612 & 58.66 \\
\hline Aspergillus niger APBSDSF96 & 95.22 & 0.0 & 590 & 58.31 \\
\hline Aspergillus fumigatus FJAT-31052 & 99.30 & 0.0 & 583 & 57.98 \\
\hline Aspergillus flavus EFB01 & 99.29 & & 588 & 56.8 \\
\hline Penicillium simplicissimum SNB-VECD11G 89.91 & $2 \mathrm{e}-147$ & 579 & 53.54 \\
\hline
\end{tabular}


Table 6: Gene Statistics using FGENESB

\begin{tabular}{|c|c|c|c|c|c|}
\hline Organism & $\begin{array}{l}\text { Closest } \\
\text { organism }\end{array}$ & $\begin{array}{l}\text { No of } \\
\text { Predicted } \\
\text { protein } \\
\text { coding } \\
\text { genes }\end{array}$ & $\begin{array}{l}\text { No. of } \\
\text { Operons }\end{array}$ & $\begin{array}{l}\text { No of } \\
\text { stranscript } \\
\text { units }\end{array}$ & Predicted proteins \\
\hline T. gamsii P2-18 & $\begin{array}{l}\text { C. } \\
\text { pefringes }\end{array}$ & 4 & 1 & 2 & $\begin{array}{l}\text { MPVRASFQPSNPPGGRRWGSGTPQTGSRPRNTVAVSPQPLLRSSLHNSHRERGASTCRKT } \\
\text { P } \\
\text { MTLGQACPPEYWRAQCAFKDSMIH } \\
\text { MPARILAGAMCVQRFDDSLNSAIHITYRISLRSSSMPEPRDPLLKVLIHFDFLLRAVKIT } \\
\text { SARGLQ } \\
\text { LVGPSAAPGSGLRRTRGVTPRAQFGMFTWVGVVTRNDPSAGSQRNLYIFYF }\end{array}$ \\
\hline $\begin{array}{l}\text { A. flavus JN-YG- } \\
3-5\end{array}$ & pefringes & 2 & 0 & 2 & $\begin{array}{l}\text { LRPLVFRGACLSERHCCPSSTACVLGRRPLSGGDGPQRQRRHRVRSSSVWGFVTRSVGPA } \\
\text { GAARTQINLTT } \\
\text { MGSNDARTGMPPGIPGGAMCVQRLDDSRNSAIHTSYRISLRSSSMPEPRDPLLKVLTDCD } \\
\text { TINSDFTRSDRVRGVSGGRGPGAESPRRP }\end{array}$ \\
\hline $\begin{array}{l}\text { A. niger } \\
\text { APBSDSF96 }\end{array}$ & \begin{tabular}{|l|} 
C. \\
pefringes
\end{tabular} & 2 & 1 & 1 & $\begin{array}{l}\text { MVGIRRQAPANPTEHVTKPHTLEDRTRCRRCLSGPSPRRGGRRPNTQAGLEGSNDARTGM } \\
\text { PPGIPGGAMCVQRLDDSLNSAIHISYRISLRSSSMPEPRDPLLKVLTDCIQSTQTARFQT } \\
\text { VFVLGSPAGTGPGGQRRPPRRPTRGRGPAESHRGNNRHGMGGWAPKDPALG } \\
\text { LGPKGPGTRVMILPQGSPTETLGYDF }\end{array}$ \\
\hline \begin{tabular}{|l} 
A. fumigatus \\
FJAT-31052
\end{tabular} & \begin{tabular}{|l|} 
C. \\
pefringes
\end{tabular} & 2 & 0 & 2 & \begin{tabular}{|l|} 
MGLCHLLCRPGRRQPTPNFIY \\
VTKPHTLEDRTRCRRCLSGPSPGRGGRGPNTQAVLEGSNDARTGMPPGIPGGAMCVQRLD \\
DSLNSAIHITYRISLRSSSMPEPRDPLLKVLTDYDNQLRLHTFRTAFMLGSSAGAGPGAQ \\
GLPGGRRNGGPAEATRYDRHGWEVGPTGPSLGNDPSAGSPTETLLRFFTS
\end{tabular} \\
\hline A. flavus EFB01 & $\begin{array}{l}\text { C. } \\
\text { pefringes }\end{array}$ & 2 & 0 & 2 & $\begin{array}{l}\text { LRPLVFRGACLSERHCCPSSTACVLGRRPLSGGDGPQRQRRHRVRSSSVWGFVTRSVGPA } \\
\text { GACRTQINLST } \\
\text { MGSNDARTGMPPGIPGGAMCVQRLDDSRNSAIHTSYRISLRSSSMPEPRDPLLKVLTDCD } \\
\text { TINSDFTRSDRVRGVSGGRGPGAESPRRP }\end{array}$ \\
\hline \begin{tabular}{|l|}
$P$. \\
simplicissimum \\
SNB-VECD11G
\end{tabular} & $\begin{array}{l}\text { C. } \\
\text { pefringes }\end{array}$ & 5 & 2 & 3 & $\begin{array}{l}\text { LLYNRLLIGPTERVTNTIRSRTGRGAAAAFRARPPGAGGRSPTHKPA } \\
\text { VPPLPFGPAPREPGGEAQHTSRLEGSNDARTGMPPEIPGGAMGVQRLDVSLISDIQLRID } \\
\text { FAAFFIEAEQKTVVEV } \\
\text { VLSYLCSGAPSRPPGASAPGPCREDTNNSVEDAVEQIS } \\
\text { MPPAAVRGPPNTGTITRGRWPRGLPECPSRSLDGCTNGIPPRPRGPIF } \\
\text { MHARPTGVQRFRPCLQAPAFRGCHCLVPVFEFAAPPHVRAAIMRRL }\end{array}$ \\
\hline
\end{tabular}


Table 7

Gene predictions

\begin{tabular}{|c|c|c|c|c|}
\hline T. gamsii P2-18 & A. flavus JN-YG-3-5 & A. niger APBSDSF96 & $\begin{array}{l}\text { A. fumigatus FJAT- } \\
31052\end{array}$ & A. flavus EFB01 \\
\hline NMS; neuromedin S & Granulins isoform & guanylate kinase & glycosyltransferase & $\begin{array}{l}\text { A-kinase anchor } \\
\text { protein }\end{array}$ \\
\hline NUDIX hydrolase & Phosphoinositide phosphatase & $\begin{array}{l}\text { metastasis suppressor } \\
\text { protein }\end{array}$ & Zinc finger protein & $\begin{array}{l}\text { Histone-lysine } \mathrm{N} \text { - } \\
\text { methyltransferase }\end{array}$ \\
\hline modular polyketide synthase & Prestalk protein & glutamate-rich protein & $\begin{array}{l}\text { Hydroxytryptamine } \\
\text { receptor }\end{array}$ & $\begin{array}{l}\text { L-sorbosone } \\
\text { dehydrogenase }\end{array}$ \\
\hline Protein transport protein & Tyrosine-protein kinase & patatin-like phospholipase & $\begin{array}{l}\text { Intestine-specific } \\
\text { homeobox isoform }\end{array}$ & $\begin{array}{l}\text { Major facilitator } \\
\text { superfamily }\end{array}$ \\
\hline Peptidase & Clc chloride channel & beta-1,2-xylosyltransferase & Thyroglobulin & $\begin{array}{l}\text { Phosphatidylinositol } \\
4,5 \text { biphosphate kinase }\end{array}$ \\
\hline formin-1 & transmembrane protein & $\begin{array}{l}\text { Cardiomyopathy- } \\
\text { associated protein }\end{array}$ & Cytochrome P450 & \\
\hline WD repeat containing protein & Senescence-associated protein & Zinc finger protein & Epoxide hydrolase & \\
\hline anaphase-promoting complex & Sphingomyelin phosphodiesterase & $\begin{array}{l}\text { NLR family CARD domain } \\
\text { protein }\end{array}$ & Peptide synthetase & \\
\hline Multiple epidermal growth factor & Phosphatidylserine decarboxylase & Cysteine proteinase & $\begin{array}{l}\text { Peptidyl-prolyl cis- } \\
\text { trans isomerase }\end{array}$ & \\
\hline leukocyte receptor cluster member & $\begin{array}{l}\text { Putative Lacl family transcriptional } \\
\text { regulator }\end{array}$ & Galactoside & $\begin{array}{l}\text { ATR-interacting } \\
\text { protein }\end{array}$ & \\
\hline amino acid transporter & MFS transporter & Myocilin & $\begin{array}{l}\text { Molybdenum } \\
\text { cofactor }\end{array}$ & \\
\hline Xenobiotic-transporting ATPase & $\begin{array}{l}\text { Egln1; egl-9 family hypoxia } \\
\text { inducible factor } 1\end{array}$ & Lactate dehydrogenase & $\begin{array}{l}\text { Histone-lysine } \mathrm{N}- \\
\text { methyltransferase }\end{array}$ & \\
\hline Radical SAM superfamily enzyme & dachshund homolog 2 isoform X1 & $\begin{array}{l}\text { Senescence-associated } \\
\text { protein }\end{array}$ & Diguanylate cyclase & \\
\hline serine carboxypeptidase & $\begin{array}{l}\text { tyrosine-protein phosphatase non- } \\
\text { receptor }\end{array}$ & sugar kinase & $\begin{array}{l}\text { Metabotropic } \\
\text { glutamate receptor }\end{array}$ & \\
\hline $\begin{array}{l}\text { amino acid adenylation domain } \\
\text { containing protein }\end{array}$ & NusB antitermination factor & $\begin{array}{l}\text { Pyridine nucleotide- } \\
\text { disulfide oxidoreductase }\end{array}$ & $\begin{array}{l}\text { A-factor } \\
\text { biosynthesis protein }\end{array}$ & \\
\hline tyrosine-protein kinase receptor & $\begin{array}{l}\text { Mandelate racemase/muconate } \\
\text { lactonizing protein }\end{array}$ & collagen alpha-1 & Metalloproteinase & \\
\hline carboxypeptidase D & Cytochrome P450 & SGNH hydrolase & $\begin{array}{l}\text { Tyrosine-protein } \\
\text { kinase }\end{array}$ & \\
\hline NADPH dehydrogenase & MATN4; matrilin-4 isoform X1 & Reductases & $\begin{array}{l}\text { ATR-interacting } \\
\text { protein }\end{array}$ & \\
\hline $\begin{array}{l}\text { N-acetylglucosamine-1- } \\
\text { phosphodiester }\end{array}$ & $\begin{array}{l}\text { slitrk3; SLIT and NTRK-like protein } \\
3\end{array}$ & $\begin{array}{l}\text { oxidoreductase } \\
\text { neomenthol } \\
\text { dehydrogenase }\end{array}$ & Sulfatase protein & \\
\hline o-succinylbenzoate-CoA ligase & zinc finger protein 575 & Exopolyphosphatase & Sulfatase protein & \\
\hline $\begin{array}{l}\text { Cation-independent mannose-6- } \\
\text { phosphate receptor }\end{array}$ & collagen alpha-1(I) chain-like & $\begin{array}{l}\text { AMP-dependent } \\
\text { synthetase and ligase }\end{array}$ & $\begin{array}{l}\text { Bifunctional DNA } \\
\text { primase/polymerase }\end{array}$ & \\
\hline auxin efflux carrier component & A-kinase anchoring protein 8 & $\begin{array}{l}\text { VSS10 domain-containing } \\
\text { receptor SorCS2 isoform }\end{array}$ & $\begin{array}{l}\text { SPARC related } \\
\text { modular calcium } \\
\text { binding }\end{array}$ & \\
\hline auxin response factor & $\begin{array}{l}\text { telomere-associated protein RIF1 } \\
\text { isoform X1 }\end{array}$ & & $\begin{array}{l}\text { Senescence- } \\
\text { associated protein }\end{array}$ & \\
\hline auxin efflux carrier component & $\begin{array}{l}\text { MORN1; MORN repeat-containing } \\
\text { protein } 1\end{array}$ & & & \\
\hline NAD epimerase/dehydratase & $\begin{array}{l}\text { CSPG5; chondroitin sulfate } \\
\text { proteoglycan } 5\end{array}$ & & & \\
\hline $\begin{array}{l}\text { Mitogen-activated protein kinase } \\
\text { Dual oxidase }\end{array}$ & $\begin{array}{l}\text { LMOD3; leiomodin-3 } \\
\text { Myelin protein zero }\end{array}$ & & & \\
\hline $\begin{array}{l}\text { Small conductance calcium- } \\
\text { activated potassium channel } \\
\text { protein } 2\end{array}$ & hypoxia-inducible factor 3-alpha & & & \\
\hline $\begin{array}{l}\text { FxsA cytoplasmic membrane } \\
\text { protein }\end{array}$ & $\begin{array}{l}\text { LOW QUALITY PROTEIN: caskin-1- } \\
\text { like }\end{array}$ & & & \\
\hline Ubiquitin protein ligase & A-kinase anchoring protein 8 & & & \\
\hline \multirow[t]{8}{*}{ phosphatidylinositol 4-kinase } & $\begin{array}{l}\text { telomere-associated protein RIF1 } \\
\text { isoform X1 }\end{array}$ & & & \\
\hline & $\begin{array}{l}\text { FSIP2; fibrous sheath-interacting } \\
\text { protein } 2\end{array}$ & & & \\
\hline & $\begin{array}{l}\text { IQSEC2; IQ motif and SEC7 } \\
\text { domain-containing protein } 2 \\
\text { isoform X1 }\end{array}$ & & & \\
\hline & $\begin{array}{l}\text { single-stranded DNA-binding } \\
\text { protein 4-like }\end{array}$ & & & \\
\hline & $\begin{array}{l}\text { tbc1d5; LOW QUALITY PROTEIN: } \\
\text { TBC1 domain family member } 5\end{array}$ & & & \\
\hline & cyclin-dependent kinase C-1 & & & \\
\hline & subtilase family protease & & & \\
\hline & $\begin{array}{l}\text { putative AraC family } \\
\text { transcriptional regulator }\end{array}$ & & & \\
\hline
\end{tabular}




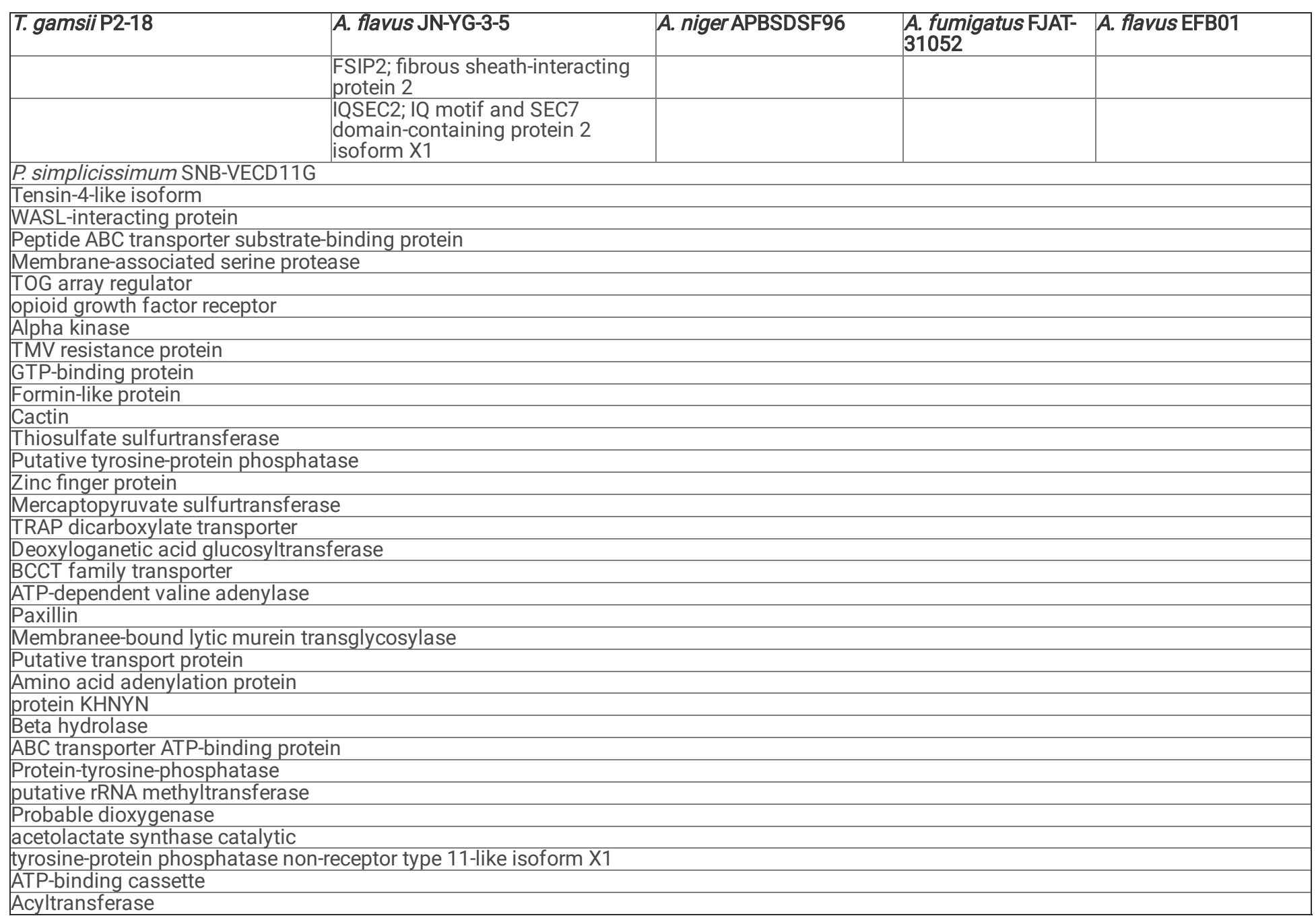

\section{Figures}

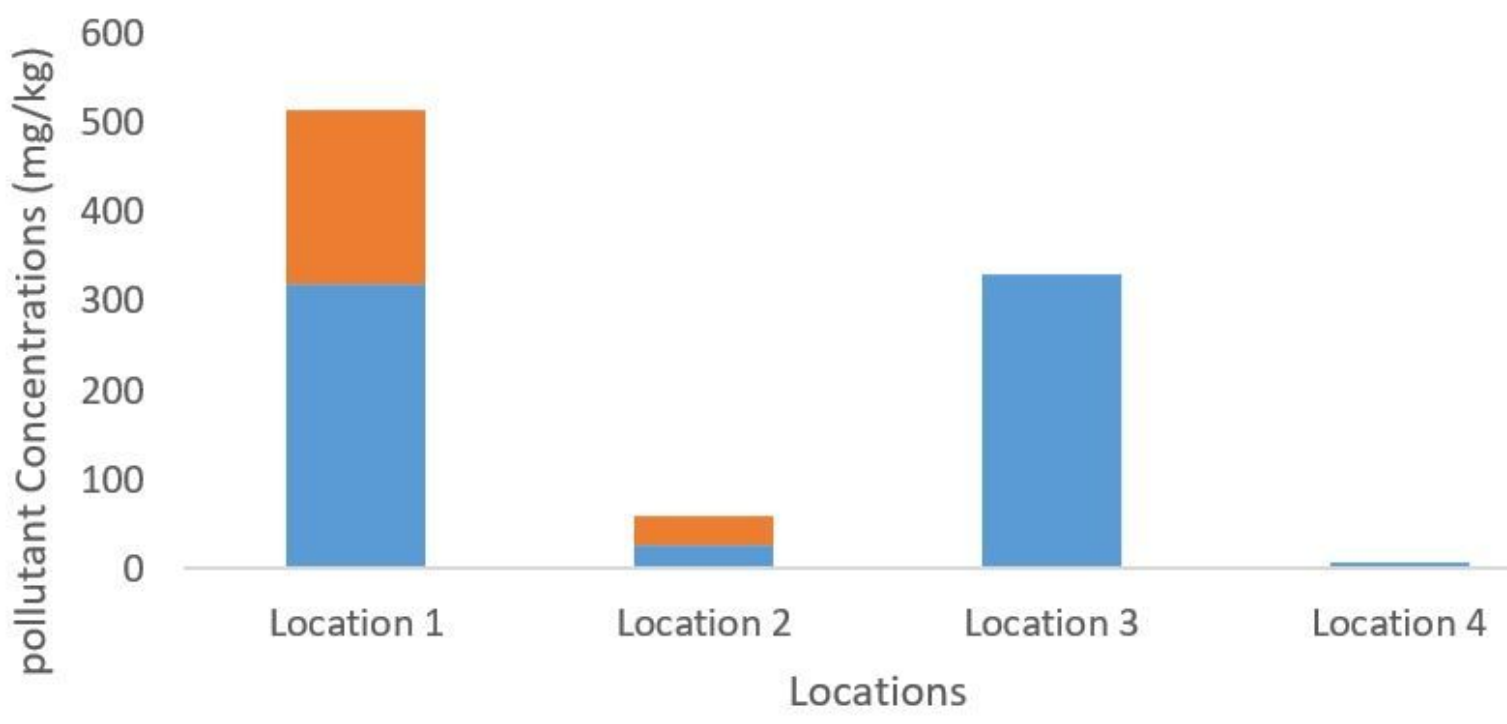

- Glyphosate $(\mathrm{mg} / \mathrm{Kg}) \quad$ AMPA $(\mathrm{mg} / \mathrm{Kg})$

\section{Figure 1}

The initial glyphosate residue of the different soil samples (* AMPA - a-amino-3-hydroxy-5-methyl-4-isoxazolepropionic acid) 


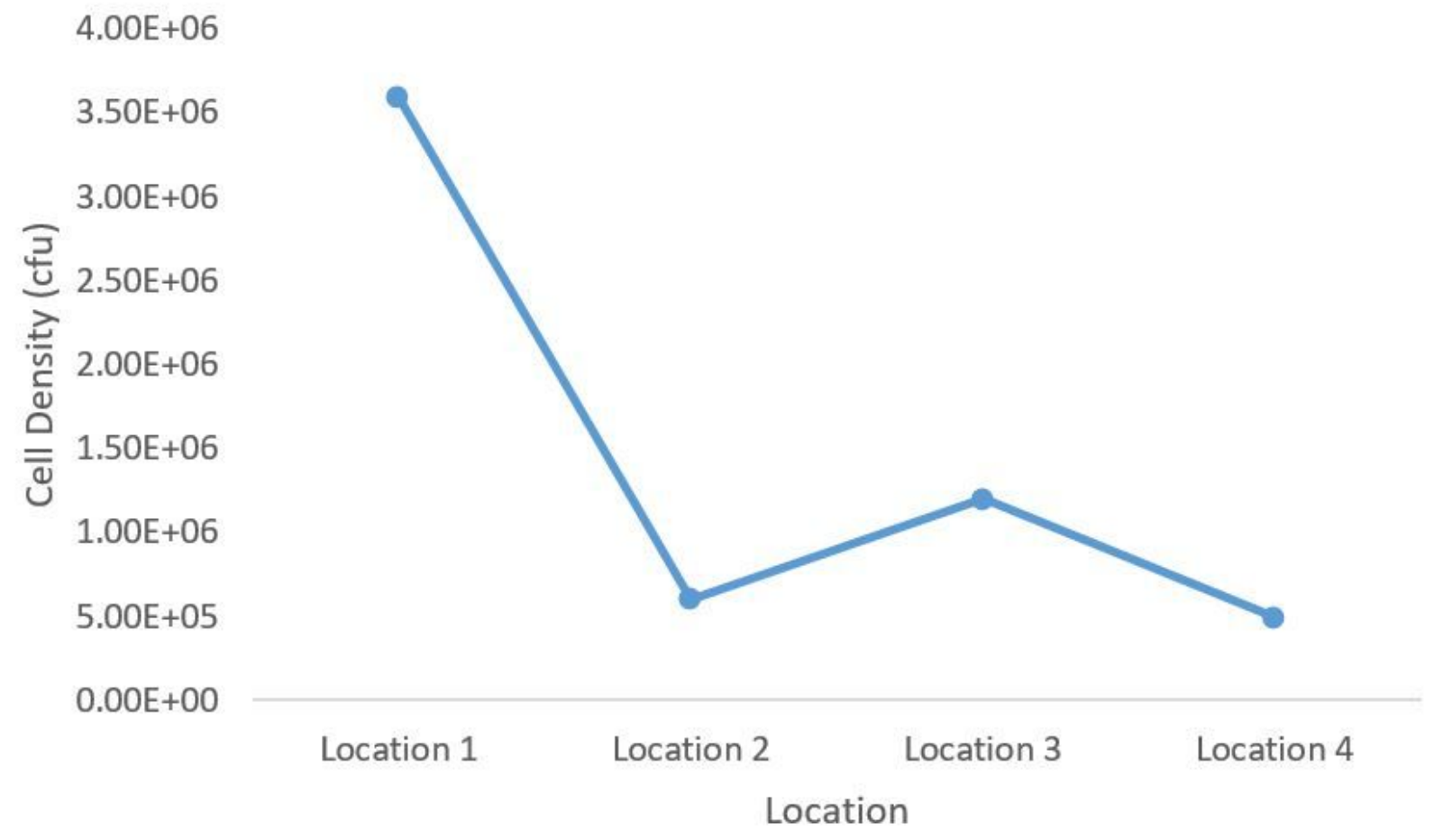

Figure 2

Fungal counts (CFU) of soil samples from the different locations

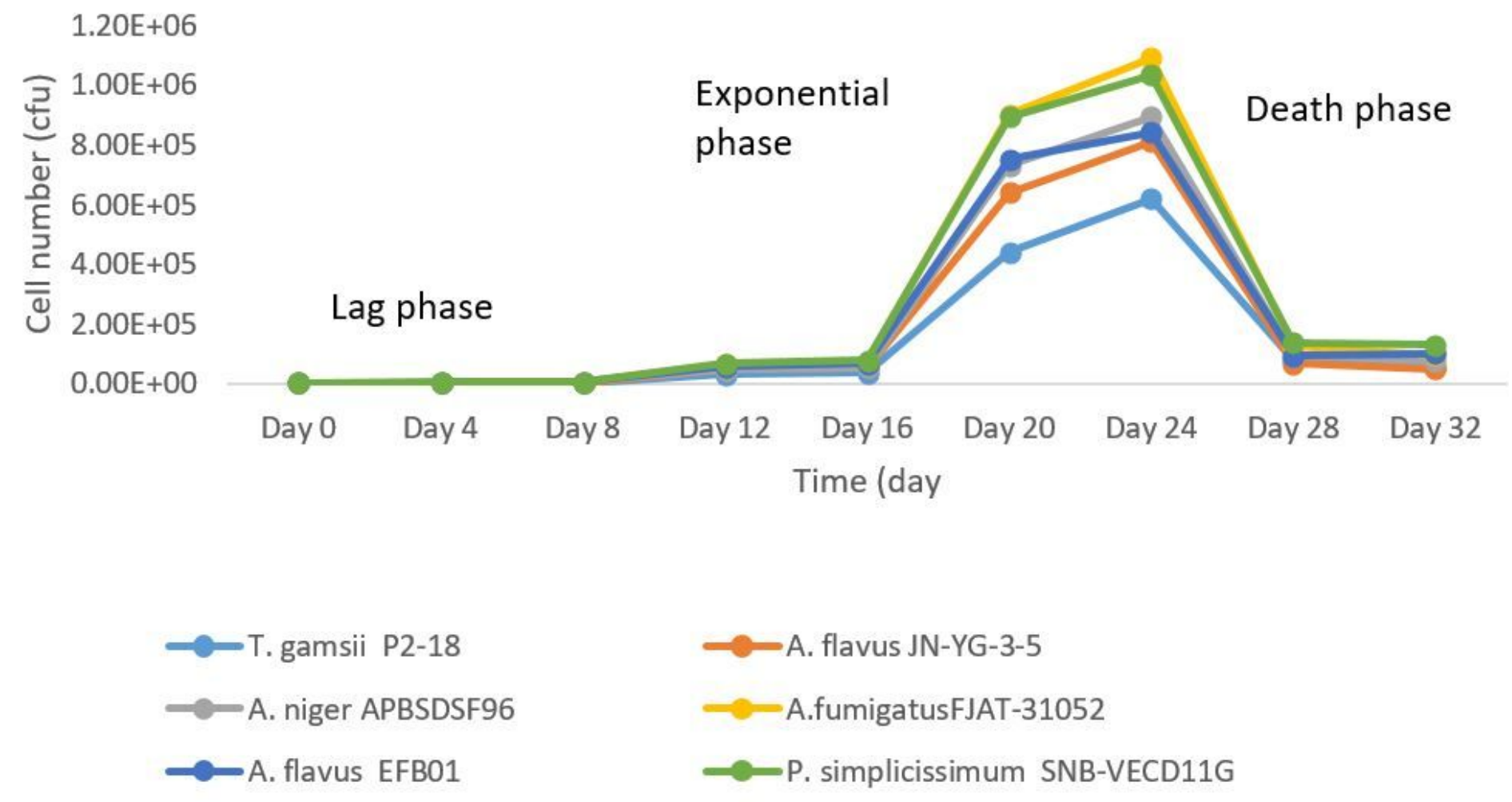

Figure 3

The analysis of viable fungal count in all the samples at different days. 


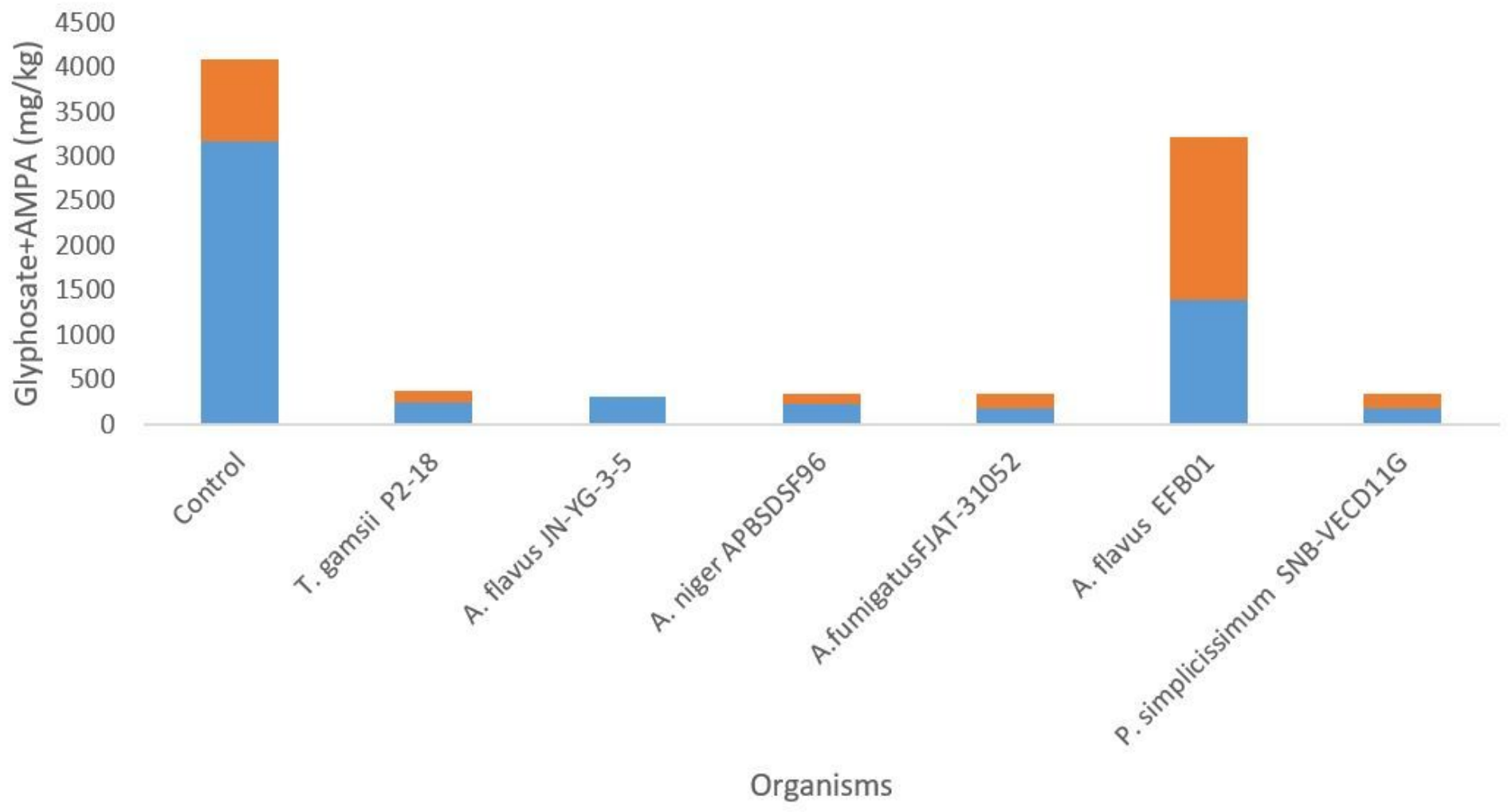

- Glyphosate $(\mathrm{mg} / \mathrm{kg})$ AMPA $(\mathrm{mg} / \mathrm{kg})$

\section{Figure 4}

Glyphosate biodegradation by the various organisms

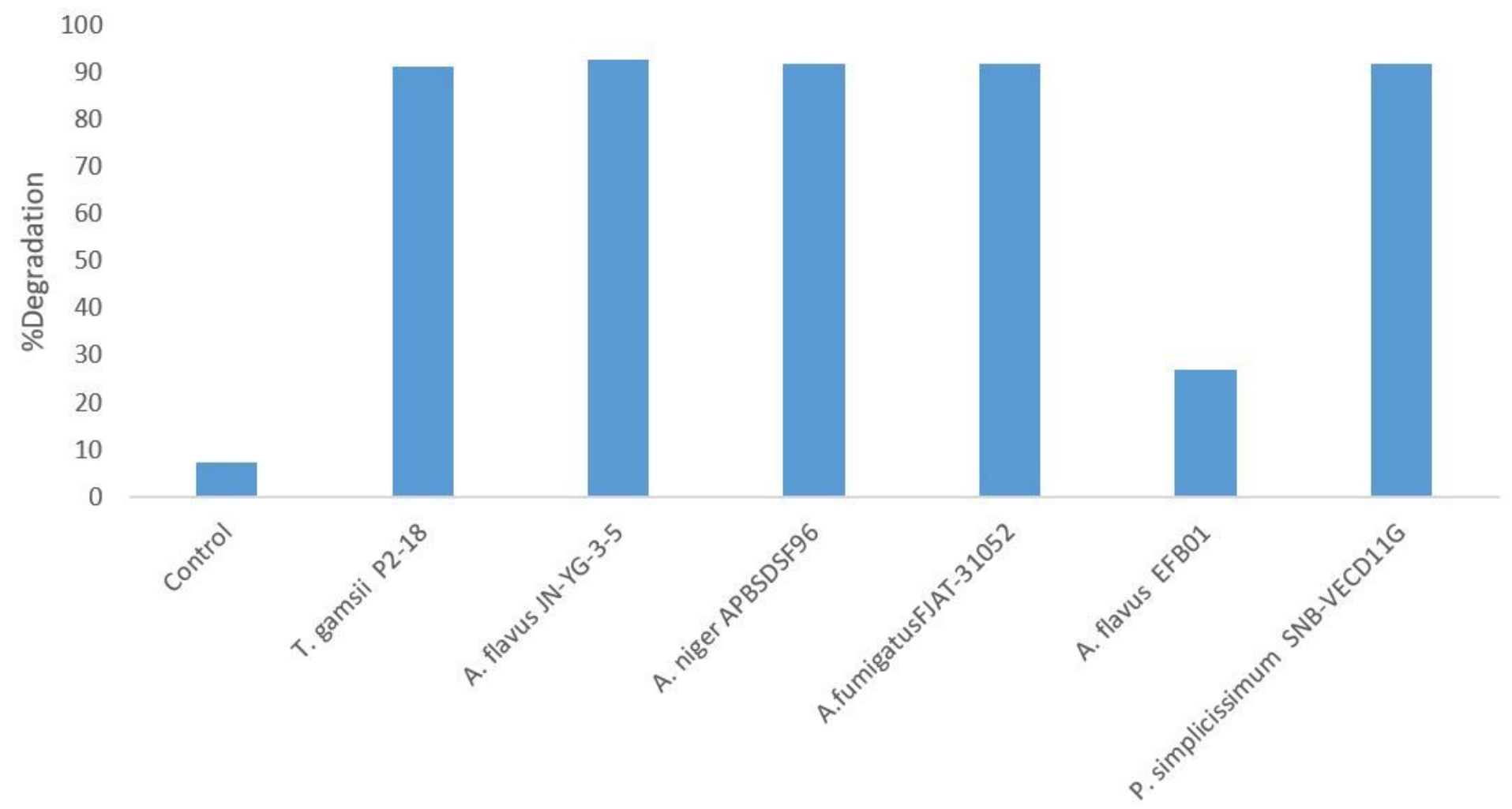

Time

Figure 5 


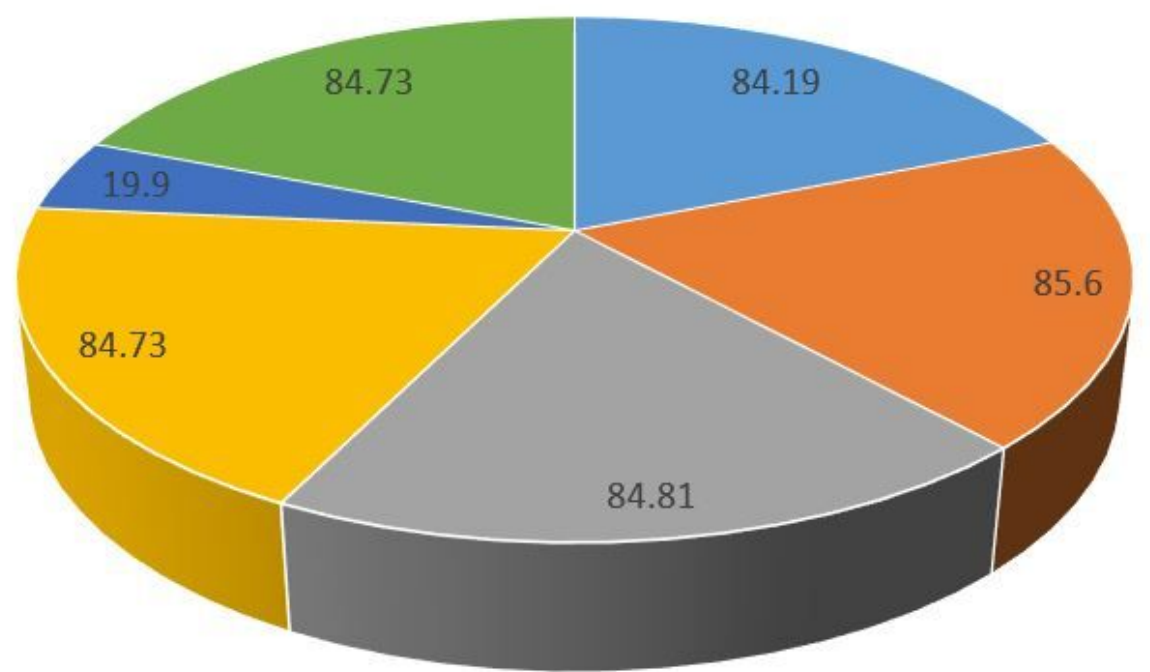

- T. gamsii P2-18
- A.fumigatusFJAT-31052

- A. flavus JN-YG-3-5

- A. flavus EFB01
- A. niger APBSDSF96

- P. simplicissimum SNB-VECD11G

\section{Figure 6}

Degradation coefficient of glyphosate by the various organisms 


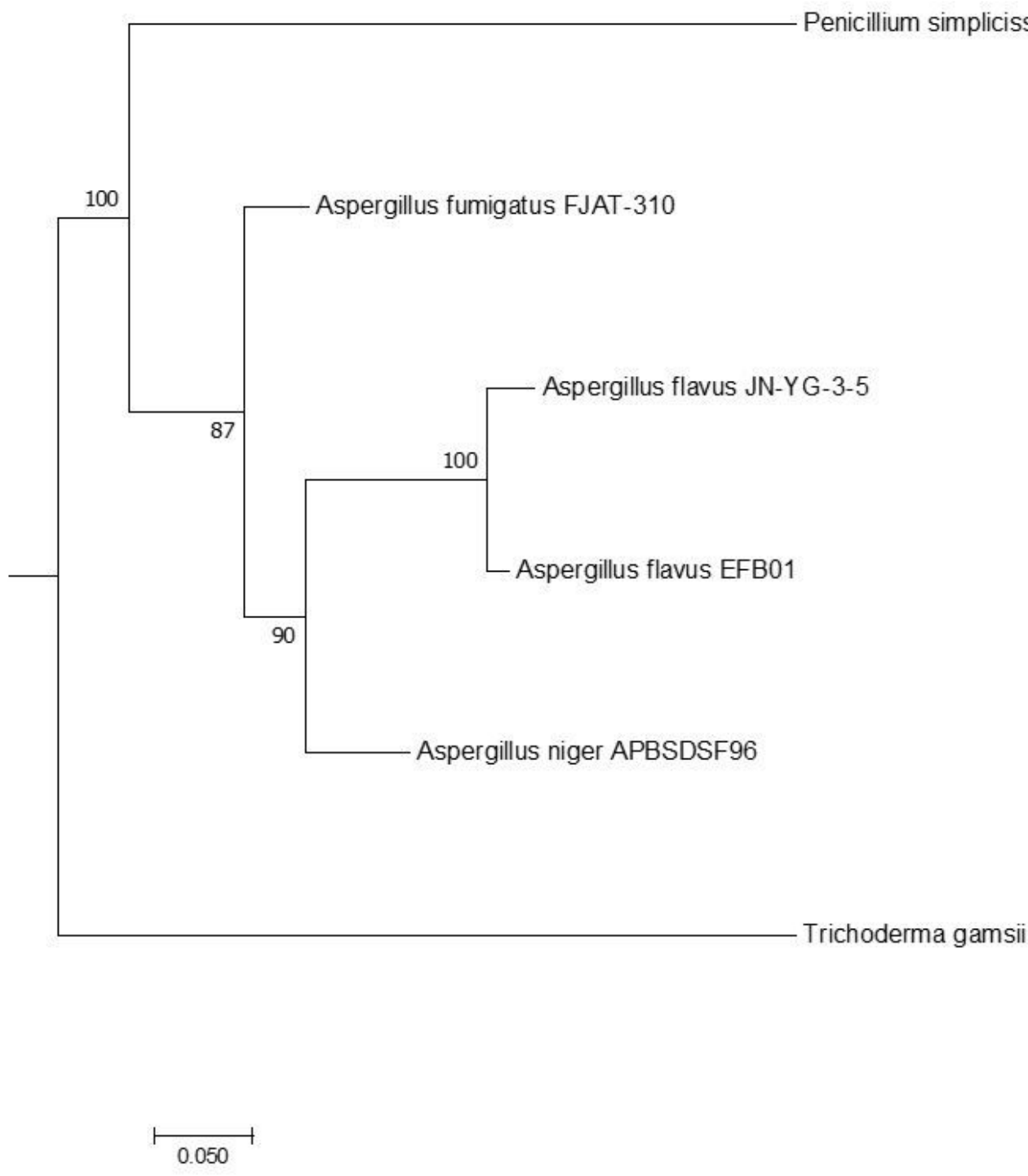

Figure 7

Phylogenetic relationship of bacterial isolates 